\title{
ECONOMICS OF CROWDFUNDING BY WHAT-IF ANALYSIS APPROACH
}

\author{
Ieva Astrauskaite \\ Vilnius University, Lithuania
}

\begin{abstract}
Fund raising alternative, demand forming activity, information spreading and sharing instrument, strengthening the communities and expanding networks, a tool for socialization these are the crowdfunding benefits to economics. However, the numerical values are missing in various researches due to the novelty of factor and lack of activity in some countries. Introducing the available what-if analysis approach with such disseminations, it resulted relationships between crowdfunding and indirect impact economic indicators (e.g. unemployment, inflation, etc.) to be stronger than direct impact indicators (e.g. budget revenue). Moreover, positive scenarios were less sensitive to changes of economic indicators than negative ones.
\end{abstract}

Key words: crowdfunding, alternative finance, economic indicators, correlation

JEL code: O160, G150

\section{Introduction}

Looking back the history, crowdfunding is not a novelty. In early ages, famous musicians like Mozart and Beethoven financed their concerts and publications of new music manuscripts via advance subscriptions from interested parties. Furthermore, the Statue of Liberty in New York was funded by small donations from the American and the French people.

Since the late 1990s, crowdfunding has been developing within the Internet community, mainly in the creative industries comprising music, film and video, independent writers, journalists, publishers, creators of performing and visual arts, games, theatres etc. (Hemer, 2011). Some examples could be mentioned: in 1997, the British rock band Marillion collected US $\$ 60,000$ from their fans via an Internet call to finance their US concert tour. The designer Scott Wilson designed a collection of simple silicone rubber wrist straps for the new Apple iPod Nano to enable people to wear it like a wrist watch and received nearly US \$ 1 million from over 13,000 fans from the Internet community to finance their production and distribution. Many independent film productions have been financed through the donations of backers from the Internet.

Crowdfunding extended its profile by the industrial spread. There was a web-based appeal for funds to fans of the Swedish car Saab in order to attract the funds for car-maker who was in trouble. The British software company Trampoline Systems raised over $£ 260,000$ of equity via an Internet call to finance a specific software project. A human rights organization was trying to raise US $\$ 150,000$ in donations from the Internet community in order to buy a communications satellite to provide Internet access to people in peripheral and rural areas of third world countries. And, finally, President Barack Obama's election campaign in 2008 raised much of its cash via small donations over the Web, with about $50 \%$ coming in payments of less than US \$200. 
Recent example is more common to Lithuanian community - "Laisvès TV" (in English "Freedom TV") - internet television project. Famous Lithuanians combined their efforts and creativity in order to produce high quality TV shows, getting by $\$ 1$ dollar from its backers. So on, the monthly budget is raised till $\$ 17,341$.

These success stories encourage the discussion on crowdfunding promotion, factors influencing its development as well as on prevention of factors inhibiting it.

The research community put its efforts in the analysis of crowdfunding. Hermer (2011) took a snapshot on crowdfunding while Belleflamme et al. (2010) worked on perspectives of it. Further dynamics of crowdfunding was examined by Mollick (2014), while the spread of it by Agrawal et al. (2011), Buysere et al. (2012). The benefits and factors attracting the use of crowdfunding were an interest of research by Belleflamme et al. (2014), Agrawal et al. (2013). Individual approaches and motivation to use the crowdfunding was examined by Belleflamme et al. (2013), Gerber and Hui (2013). Rubinton (2011) introduced crowdfunding as a concept and model for the evolution of investment banking.

Moreover, often the relevance of crowdfunding is revealed by the statistics of firms' access to funding. According to the survey of ECB, Euro area SMEs considered access to finance the least important problem that they faced (10\%, down from $11 \%$ in the previous round), although results differ across countries. Finding customers remains their main concern $(27 \%$ of respondents, up from $25 \%$ in the previous round). On balance, a net $1 \%$ of SMEs reported an increase in their need for bank loans (unchanged from the previous survey round). For the third consecutive period, SMEs reported, on balance, an improvement in the availability of bank loans, a further fall in interest rates and an increase in the available size and maturity of loans and overdrafts. Of the $30 \%$ of SMEs that had applied for a loan, $68 \%$ received the full amount requested and $8 \%$ reported that their applications had been rejected (ECB, 2016).

The main goal. As far as the research on crowdfunding as a developing instrument is still poor (mainly regarding the lack of statistical data to analyze), the author of this article decided to adopt the what if analysis approach in order to investigate the impact of crowdfunding to economics of Lithuania.

The methods used. Firstly, according to the literature and the previous researches the impact variables were set. When the cases of crowdfunding were modelled, scenarios were built. Later on the counterfactual analysis was introduced.

The paper is structured as follows: the motivation and relevance of the topic is revealed in introduction, when theoretical background is introduced. The second part consists of brief methodology approach and the empirical results of the research. The paper concludes with main insights and remarks on the topic.

\section{Literature Review}

When examining the definition of crowdfunding one can identify two major features of this phenomenon. One is the size of the audience, which is attracted to funding facility. Usually those are large groups, without any other personal relationship except the interest and motivation to invest into particular project. Another - a set of tools to ensure the accessibility of funding. Nowadays, innovations and technologies substitute the regular equipment. Therefore the main tools working for crowdfunding are internet platforms. This is a way how information is split around the interest and funds are gathered. 
Table 1. Definitions of crowdfunding

\begin{tabular}{|c|c|c|}
\hline Authors & Year & Definition \\
\hline J. Hemer & 2011 & $\begin{array}{l}\text { A specific form of microfinancing of projects or ventures by } \\
\text { a large number of funders which has - for its Internet-based } \\
\text { variant - come to be known as crowdfunding. }\end{array}$ \\
\hline E. Mollick & 2011 & $\begin{array}{l}\text { Crowdfunding allows founders of for-profit, artistic, and } \\
\text { cultural ventures to fund their efforts by drawing on } \\
\text { relatively small contributions from a relatively large number } \\
\text { of individuals using the internet, without standard financial } \\
\text { intermediaries. }\end{array}$ \\
\hline $\begin{array}{l}\text { K. De Buysere, O. Gajda, R. } \\
\text { Kleverlaan, D. Marom }\end{array}$ & 2012 & $\begin{array}{l}\text { Crowdfunding, an application of crowdsourcing, is defined } \\
\text { as one party's attempt to finance a project by offering three } \\
\text { types of investment opportunities to potential investors. The } \\
\text { investment opportunities are donations, passive investments, } \\
\text { and active investments. }\end{array}$ \\
\hline B. J. Rubinton & 2011 & $\begin{array}{l}\text { Crowdfunding can be defined as a collective effort of many } \\
\text { individuals who network and pool their resources to support } \\
\text { efforts initiated by other people or organizations. This is } \\
\text { usually done via or with the help of the Internet. }\end{array}$ \\
\hline $\begin{array}{l}\text { P. Belleflamme, T. Lambert, A. } \\
\text { Schwienbacher }\end{array}$ & 2014 & $\begin{array}{l}\text { With crowdfunding, an entrepreneur raises external } \\
\text { financing from a large audience (the "crowd"), in which each } \\
\text { individual provides a very small amount, instead of soliciting } \\
\text { a small group of sophisticated investors. }\end{array}$ \\
\hline $\begin{array}{l}\text { The Law of crowdfunding of } \\
\text { Lithuania }\end{array}$ & 2016 & $\begin{array}{l}\text { Crowdfunding is defined as a method of financing through } \\
\text { the special platform, publicly announcing the project at their } \\
\text { own expense to the unrelated donors who acquire rights sold } \\
\text { in the creditor's claim. }\end{array}$ \\
\hline
\end{tabular}

*Compiled by the author

As could be seen from table 1, many authors (Hemer, 2011; Mollick, 2011; Rubinton, 2011; Belleflamme et al., 2014) agree on crowdfunding being collective, organized funding activity, which works with the help of the Internet. Mostly small amounts of sums are pooled in order to fulfill the larger needs of other people, organizations on behalf of their projects. While Hemer (2011) intends on microfinancing, Agrawal et al. (2011) emphasizes the broad geographic dispersion of crowdfunding, where large scale projects are funded as well. Specifying the users of crowdfunding, Mollick (2011) distinguishes for-profit, artistic, and cultural ventures, Rubinton (2011) generalizes it to other people and organizations. It is important to mention that all investors are supposed to be individual, independent, unrelated (Rubinton, 2011; Belleflamme et al., 2014; The Law of crowdfunding..., 2016). Moreover, crowdfunding is described as an alternative to small group of sophisticated investors (Belleflamme et al., 2014). 
To sum up, different kind of features are emphasized while crowdfunding is described. Most common are the way of organizing it and the tool used.

Even in its definition one can observe the measures for crowdfunding classification. Buysere et al. (2012) discern donations, passive investments, and active investments. While donations do not yield the crowdfunder any type of material reward, both passive and active investments do encompass some form of material reward (Gueyie et al., 2013). Active investments grant the crowdfunder with opportunity to influence the investment, while passive investment strategy relieves any action granting a reward.

A crowdfunder choice of actively or passively participation in funding process is often related to other motivations of this process. Usually active crowdfunders provide the organization with funds and information or work. These investors involve themselves into the business becoming the first customers, giving the first critics to the products or having the voting rights in particular management decisions. This is highlighted by Belleflamme et al. (2010), stating that crowdfunding is not just about funding; it is also about information. Crowdfunding can be used as a promotion device, as a means to support mass customization or user-based innovation, or as a way for the producer to gain a better knowledge of the preferences of its consumer. Moreover, in most of the cases, the compensation is to receive a product or service from the financed activity. Hence, crowdfunding blurs the usual divide between the roles of investors and of customers: some investors are customers and some customers are investors (Belleflamme et al., 2010).

Meanwhile, passive crowdfunders are solely interested in raising money without any kind of participation in the business. Donators usually are idea-motivated, socially responsible, without any other financial intentions on reward, except self-satisfaction with some karma points.

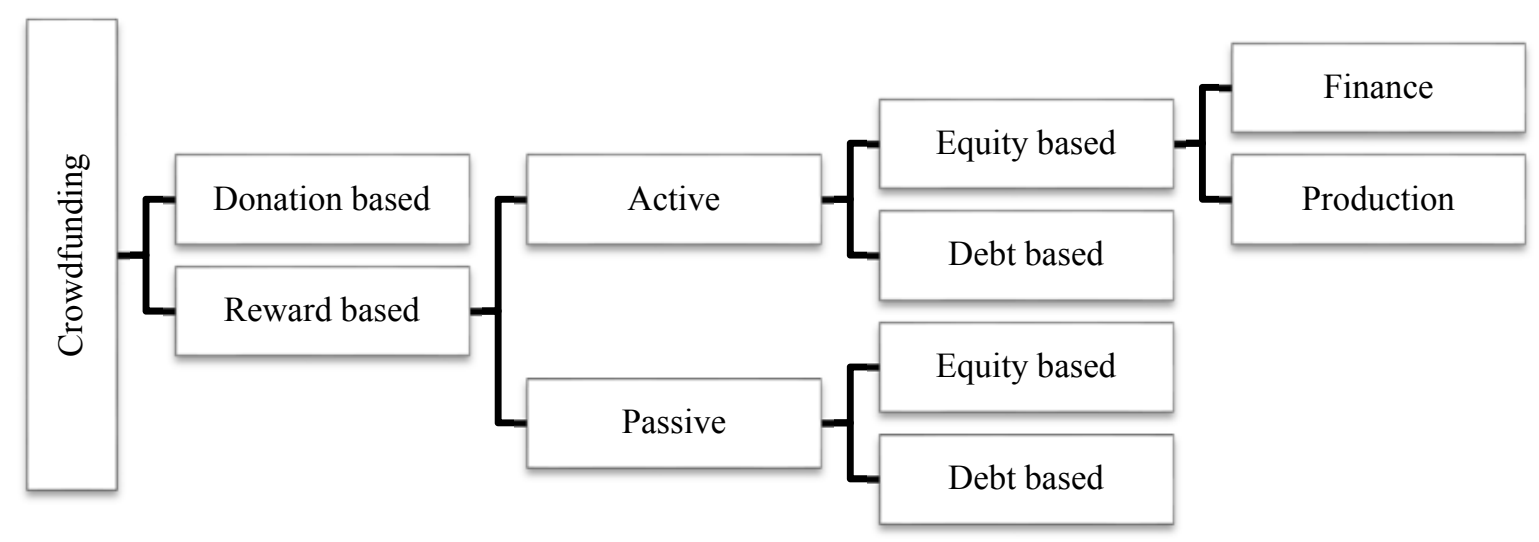

Figure 1. Classification of Crowdfunding

(*compiled by author) 
Basically most authors (Lambert and Schwienbacher, 2010; Buysere et al, 2012; Rubinton, 2011;) distinguish there are four types of crowdfunding: donation-based, reward- based, equity-based, and lending or debt- based. However, regarding the literature analysis the author of this paper provides a wider classification of crowdfunding denoting the reward (which could be material or intangible), kind of crowdfunder's role in participation (active or passive):

$\rightarrow$ Donation: a donor contract without existential reward. Crowdfunding is based on the fact that people want to help other people and projects they like and that are close to them, emotionally or geographically (Buysere et al, 2012). Crowdfunding initiatives that are structured as nonprofit organizations tend to be significantly more successful than other organizational forms in achieving their fundraising targets. This finding is in line with theoretical arguments developed by the contract failure literature which postulates that nonprofit organizations may find it easier to attract money for initiatives that are of interest for the general community due to their reduced focus on profits (Belleflamme et al,2013).

$\rightarrow$ Reward: a contract with existential material reward (in money or production).

$\rightarrow$ Lending: a credit contract, that is being repaid plus interest.

$\rightarrow$ Equity: a shareholding contract, shares, equity-like instruments or revenue sharing in the project/business, potential up-side at exit. There can also be non-financial equity, e.g. a purchase of contract for some type of product or service.

While the types of crowdfunding and motives to participate are examined, the acting roles and whole process should be clarified to proceed with its economics.

Buysere et al (2012) emphasize the actors of crowdfunding who are project owners (entrepreneurs or individuals with a specific goal), funders (investors, lenders or donors) and the crowdfunding platforms as an intermediary.

Although crowdfunding seems to belong to direct funding activities, the need of intermediary brings its perception to indirect finance (Figure.2).

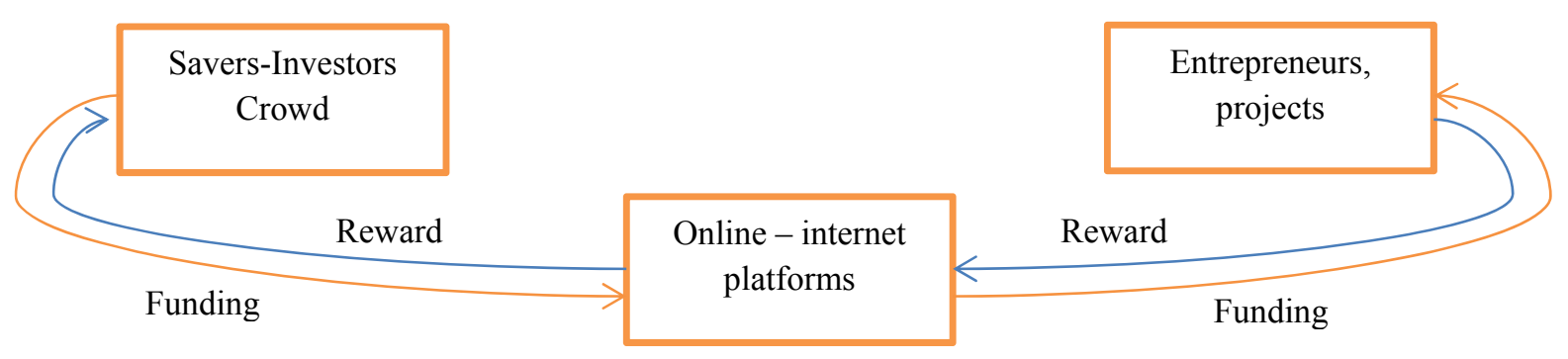

Figure 2. Process of Crowdfunding

(*compiled by author) 
The crowfunding performance is described by several steps (Buysere et al, 2012):

$\rightarrow$ Online platforms receive applications from project owners who intend to showcase their business idea or cause on the platform's website. Some platforms make a preselection of the ideas based on their own criteria, while others automatically publish every idea. Platforms that use pre-selection are checking the background of the project owner and do a quick review on the feasibility of the crowdfunding plan.

$\rightarrow$ After an idea is accepted by the online platform, the project owner is tasked with creating a funding goal over a marked period of time and an online "pitch" (most of the times in the form of a video), where the project owner pitches his/her idea to potential funders. Project owners often utilise social networks to access potential funders on a larger scale. Funders then fund the campaign directly through the online crowdfunding platform.

$\rightarrow$ During the campaign the project owner will keep his funders/fans updated about the process with updates on the online platform.

$\rightarrow$ If the funding goal is reached within the allocated fundraising time frame, the project owner receives the money. If the funding goal is not reached, most of the platforms will reimburse the money to the funders.

$\rightarrow$ In terms of post investment, some funders choose to remain involved in the decisionmaking and overall strategy of the business. Some funders receive voting rights in the business. In most cases the communication between the funders and project owners will continue through the online platform.

Taking these steps the individuals and businesses proceed to the allocation of funds. This is the core of economics.

The other pros of crowdfunding could be described as motivation factors, which are selected both by issuers (entrepreneurs, contractors, etc.) and crowdfunders (Table 2.).

Table 2. Motives of crowdfunding

\begin{tabular}{|c|c|}
\hline Creator motivations & Supporter motivations \\
\hline $\begin{array}{l}\rightarrow \text { the desire to raise funds } \\
\rightarrow \text { expand awareness of work } \\
\rightarrow \text { connect with others } \\
\rightarrow \text { gain approval } \\
\rightarrow \text { maintain control } \\
\rightarrow \text { learn } \\
\rightarrow \text { the desire to raise the demand }\end{array}$ & $\begin{array}{l}\rightarrow \text { the desire to collect rewards } \\
\rightarrow \text { help others } \\
\rightarrow \text { support causes } \\
\rightarrow \text { be part of a community } \\
\rightarrow \text { personal identification with the project's } \\
\text { subject and its goals } \\
\rightarrow \text { satisfaction from observing the realization and } \\
\text { success of the project funded } \\
\rightarrow \text { enjoyment in being engaged in and interacting } \\
\text { with the project's team } \\
\rightarrow \text { enjoying contributing to an innovation or } \\
\text { being among the pioneers of new technology } \\
\text { or business } \\
\rightarrow \text { the chance to expand one's own personal } \\
\text { network }\end{array}$ \\
\hline
\end{tabular}

Compiled by the author, according the research of Lambert and Schwienbacher (2010); Gerber and Hui (2013). 
Examining the motives of creators or initiators, one can come to the conclusion of several advantages of crowdfunding:

$\rightarrow$ Fund raising alternative;

$\rightarrow$ Demand forming activity;

$\rightarrow$ Information spreading and sharing instrument;

$\rightarrow$ Strengthening the communities and expanding networks;

$\rightarrow$ Tool for socialization.

However, there seem to be some drawbacks of crowdfunding (Buysere et al., 2012):

$\rightarrow$ Fraud. Scams could be funded through crowdfunding platforms.

$\rightarrow$ Post Investment Communication. A large number of stakeholders can be incredibly difficult to manage.

$\rightarrow$ Data, Analysis and Risk Mitigation. Individual funders often have no formal training and may not be equipped to evaluate the investment, assess the financial risks involved.

$\rightarrow$ Conflicts Of Interest \& Operational Risks. Conflicts of interest occur when owners or specific funding providers use privy information to generate systematic superior returns compared to the crowd financing it.

These are usually prevented by fear of failure or lack of trust (Gerber and Hui, 2013) and therefore the supply for crowdfunding is emerging. Moreover, the vast majority of founders seem to fulfill their obligations to funders, but that over $75 \%$ deliver products later than expected, with the degree of delay predicted by the level and amount of funding a project receives. These results offer insight that the actions of founders may affect their ability to receive entrepreneurial financing (Mollick, 2014).

As one can observe, despite the theoretical background, awareness of the process, there is little data and research made on crowdfunding's impact on economics. Basically all studies are concentrated on micro influence which is measured by surveys or case studies. The state of art of the research of crowdfunding gave the motivation to explore the what-if analysis approach in this paper.

\section{Methodology}

The most popular research methods, which were chosen for crowdfunding, were:

1. Case study - taking into account different data sets of cases, linking to particular characteristics or theories (Agrawal et al (2011), Belleflamme et al. (2013), Mollick (2014)).

2. Survey - asking investors for motives to crowdfund, and entrepreneurs - for reasons to go public. Surveys were introduced by Lambert and Schwienbacher (2010), Gerber and Hui (2013).

3. Modelling - micro and macro indicators were simulated with reference to crowdfunding by Rubinton (2011), Agrawal et al. (2013), Belleflamme et al. (2014). They highlighted the extent to which economic theory, in particular transaction costs, reputation, and market design, can explain the rise of crowdfunding (Agrawal et al., 2013), explored differences between entrepreneurs solicit individuals either to preorder the product or to advance a fixed amount of money in exchange for a share of future profits (or equity) (Belleflamme et al., 2014), analyzed the investor 
opportunities and the entrepreneur parameters sets of the game to maximize the probability of successful financing (Rubinton, 2011).

It should be noticed, that years passed and the researchers differ in methods with stability in the topic of crowdfunding. Case studies, surveys and modelling approaches are usually used to explore the subjects which domains a novelty and small data sets, which prohibit mathematical or statistical methods to take.

According the same reasons (novelty and lack of data set) the what-if analysis approach was taken to examine the crowdfunding in this paper.

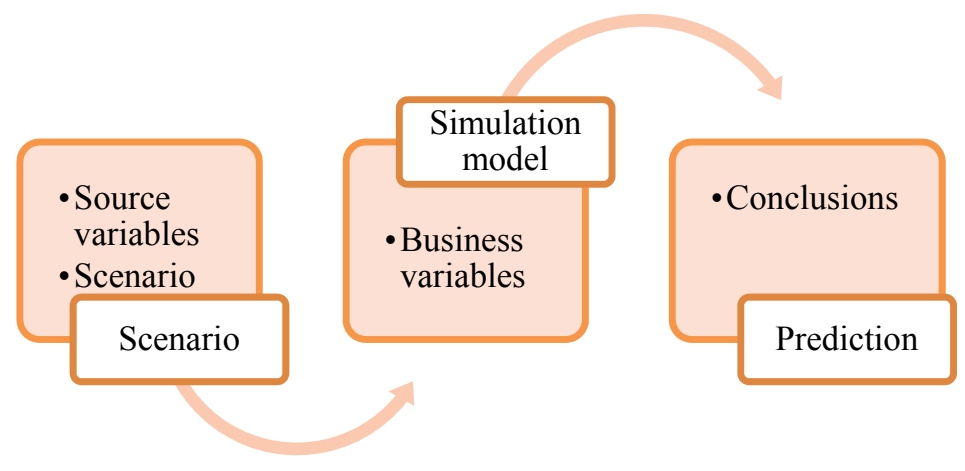

Figure3. What-if analysis approach

Compiled by author, according to Rizzi (2008)

According to Rizzi (2008), what-if application is centered on a simulation model, that establishes a set of complex relationships between some business variables corresponding to significant entities in the business domain (e.g., products, branches, customers, costs, revenues, etc.). A simulation model supports one or more scenarios, each describing one or more alternative ways to construct a prediction of interest for the user. The prediction typically takes the form of a multidimensional cube, whose dimensions and measures correspond to business variables, to be interactively explored by the user by means of any OnLine Analytical Processing (OLAP) front-end. A scenario is characterized by a subset of business variables, called source variables, and by a set of additional parameters, called scenario parameters, that the user has to value in order to execute the model and obtain the prediction (Rizzi, 2008).

Problem of the research of this paper: unknown base on which crowdfunding affects the economy of the country.

In order to test, what kind of implications could be made to country's economy two cases and several scenarios were introduced. Suppose we have a limited market of crowdfunding where reward by production and reward by services take place. Each quarter for 4 years the market was fulfilled by average of 100 contracts (both kind) and reached the project goal (100.000 EUR) by 150 per cent in average. The presumptions that reward by production contracts spend additional 2 million EUR for rewards and financial reward is equal to 5 percent were made (see Table 3). 
Table 3. Cases of analysis*

\begin{tabular}{|l|l|l|l|}
\hline \multicolumn{2}{|l|}{ Reward: production, services } & Reward: finance & \\
\hline Project goal, EUR & $100.000,00$ & Project goal, EUR & $100.000,00$ \\
\hline Number of projects & 100 & Number of projects & 100 \\
\hline Funded, \% & $150 \%$ & Funded, \% & $150 \%$ \\
\hline Reward service cost, EUR & $2.000 .000,00$ & Reward, 5\% & $7.500,00$ \\
\hline Additional finance & $13.000 .000,00$ & Additional finance & $14.992 .500,00$ \\
\hline
\end{tabular}

*compiled by author

These cases were compiled to briefly represent the crowdfunding market.

Afterwards, economic indicators were chosen. The main criteria for indicator was it should represent the country's economy and wealth. The indicators could be divided into direct and indirect impact on crowdfunding. For example, the state budget revenue could be affected directly by gathering taxes from rewarded investors (e.g. income tax) or spending gathered money by entrepreneurs (e.g. investing in new facilities, creating jobs, paying income taxes, etx.). If all the money from $1^{\text {st }}$ quarter cases were equally separated to become a tax base of income and VAT taxes, it would resulted following revenue to the state budget:

Table 4. Example of direct crowdfunding impact on economy*

\begin{tabular}{|l|l|l|l|l|l|}
\hline Tax revenue & & $\begin{array}{l}\% \text { of } \\
\text { total } \\
\text { state } \\
\text { budget }\end{array}$ & Tax revenue & $\begin{array}{l}\% \text { of } \\
\text { total } \\
\text { state } \\
\text { budget }\end{array}$ \\
\hline Income tax, EUR & $1.125 .000,00$ & $0,1 \%$ & Income tax, EUR & $1.125 .000,00$ & $0,1 \%$ \\
\hline VAT, EUR & $1.575 .000,00$ & $0,05 \%$ & VAT, EUR & $1.574 .212,50$ & $0,05 \%$ \\
\hline
\end{tabular}

*compiled by author

All together from income ${ }^{1}$ and $\mathrm{VAT}^{2}$ taxes the state (in current example the state of Lithuania) would gain less than 0,2 per cent of its overall income from stated taxes. As one

\footnotetext{
${ }^{1} 15$ per cent
} 
could observe from the Table 4, the differences between the state budget revenue generated by different cases are so slight, that aftermath analysis is made under one case, supposing the conclusions would be adequate.

Other indicators representing the economy of the state were mostly of indirect impact of crowdfunding:

- Unemployment, \%

- Inflation, \%

- GDP per capita, EUR

- Average wage before taxes, EUR

Then the scenarios were build, differing on the dynamics of crowdfunding related to growth rates of GDP.

Scenario 1 (Basic): what if the market of crowdfunding is growing within the GPD $(=1)$;

Scenario 2 (Optimistic): what if the market of crowdfunding is growing within the GPD $(=2)$;

Scenario 3 (Pessimistic): what if the market of crowdfunding is growing within the GPD $(=0,5)$;

Scenario 4 (Realistic): what if the market of crowdfunding is growing within the GPD $(=1,25)$;

All the dynamics was adjusted by growth rates and the correlations with economic indicators were introduced. GDP per capita was eliminated due to the equal 1 correlation. The correlations were counted according Pearson (r) formula and methodology, using MS Excel instrument. It ( $\mathrm{r}$ ) has a value between +1 and -1 , where 1 is total positive linear correlation, 0 is no linear correlation, and -1 is total negative linear correlation. The closer the value is to 1 or -1 , the stronger the linear correlation. "White noise" tests were applied.

The scenarios were adopted to crowdfunding case and the impact on correlation ratios was measured. Conclusions were made.

\section{Empirical results}

According to the Scenario 1 (Basic) the crowdfunding and economic indicators' correlations were formed as follows (see Table 5).

\footnotetext{
${ }^{2} 21$ per cent
} 
Table 5. Results of Scenario 1 (Basic)*

\begin{tabular}{|r|c|}
\hline Correlations to & r \\
\hline unemployment & $-0,53$ \\
\hline inflation & \\
\hline av.wage & 0,43 \\
\hline budget revenue & 0,50 \\
\hline
\end{tabular}

*compiled by author

To sum up, the unemployment and crowdfunding market has middle strong negative $(\mathrm{r}=-0,53)$ linear correlation. When there are growing crowdfunding funds, the unemployment is decreasing. It should be noted that only dynamics not causal relations are examined. Inflation, wage and budget indicators could be described as of middle strong positive correlation to crowdfunding ( $\mathrm{r}$ meanings around 0,5 ). When crowdfunding projects increase, the inflation, average wage in the country and budget revenue indicators also increase.

All measures were checked with 95 per cent probability and two-tailed distribution, having $\mathrm{p}$ values above the 0,05 meaning. That imposes above implications being not significant. These findings could be correct by enlarging the set of data.

According to the Scenario 2 (Optimistic) the crowdfunding and economic indicators' correlations were counted as follows (see Table 6).

Table 6. Results of Scenario 2 (Optimistic)*

\begin{tabular}{|r|c|}
\hline Correlations to & r \\
\hline unemployment & $-0,51$ \\
\hline inflation & \\
\hline av.wage & 0,57 \\
\hline budget revenue & 0,82 \\
\hline
\end{tabular}

*compiled by author 
As one can observe from Table 6, the correlation coefficient (r) between crowdfunding and unemployment stayed negative with comparatively the same $(\mathrm{r}=-0,51)$ meaning as in the Scenario 1 (Basic). Furthermore negative linear correlation was observed between budget revenue and crowdfunding $(\mathrm{r}=-0,06)$. Although being rather small, it supposes the crowdfunding to grow when the budget revenues to decrease. This situation could reveal the A.Laffer rule, when higher taxes (tariffs, broader tax base, etc.) lead to decreasing budget revenues. Comparing to the first scenario, the inflation indicator did not changed significantly. On the other hand, the average wage indicator seemed to rise in the same trend (from 0,5 in Table 5, to 0,82 in Table 6). This correlation should be noticed as strong one, which means that the dynamics of crowdfunding market and average wage in the country continue in the same positive trend. The larger the growth of crowdfunding strengthens the correlation with the growing average wage in the country.

As in the first scenario, all measures were checked with 95 per cent probability and two-tailed distribution, having $\mathrm{p}$ values above the 0,05 meaning. That imposes above implications being not significant. These findings could be correct by enlarging the set of data.

All measures were checked with 95 per cent probability and two-tailed distribution, having $\mathrm{p}$ values above the 0,05 meaning. That imposes above implications being not significant. These findings could be correct by enlarging the set of data.

According to the Scenario 3 (Pessimistic) the crowdfunding and economic indicators' correlations were formed as follows (see Table 7).

Table 7. Results of Scenario 3 (Pessimistic)*

\begin{tabular}{|r|c|}
\hline Correlations to & r \\
\hline unemployment & 0,85 \\
\hline inflation & \\
\hline av.wage & $-0,35$ \\
\hline budget revenue & $-0,65$ \\
\hline
\end{tabular}

*compiled by author

As could be observed from Table 7, two variable (inflation and average wage) has negative correlations with crowdfunding, differing on degree of strength. Increasing crowdfunding was strongly led by decreasing average wage and middle strong deflation. These observations could be explained by economic cycles, when all economic indicators suffer they down turns. However, crowdfunding could be explained as alternative to traditional financing. Another two economic indicators (unemployment and budget revenue) remain in positive linear dynamics with crowdfunding. While crowdfunding and unemployment strongly rose, only the small correlation could be observed with budget revenues. As one can notice, these trends of dynamics are completely opposite to Scenario 2 . 
As previously, all measures were checked with 95 per cent probability and two-tailed distribution, having $\mathrm{p}$ values above the 0,05 meaning. That imposes above implications being not significant. These findings could be correct by enlarging the set of data.

According to the Scenario 4 (Realistic) the crowdfunding and economic indicators' correlations were counted as follows (see Table 8).

Table 8. Results of Scenario 4 (Realistic)*

\begin{tabular}{|r|c|}
\hline Correlations to & r \\
\hline unemployment & $-0,76$ \\
\hline inflation & \\
\hline av.wage & 0,60 \\
\hline budget revenue & 0,98 \\
\hline
\end{tabular}

*compiled by author

Table 8 gives the following results:

- Unemployment indicator has a strong negative linear correlation with crowdfunding $(\mathrm{r}=-0.76)$ : when crowdfunding increases, unemployment decrease. This implication may lead to presumption, that the additional money from crowdfunding (the capital raised) relates to creation of more jobs in the country and lessens the unemployment rate.

- Inflation and average wage indicators were of strong positive correlation with crowdfunding. This implication may lead to presumption that the additional money from crowdfunding (the capital raised) relates to boost of overall price level as well as wages.

- The weakest positive relationship is seen between budget revenue and crowdfunding $(\mathrm{r}=0.05)$. This implication may lead to presumption, that the additional money from crowdfunding (the capital raised) relates to raising amounts of money gathered by the state budget.

All measures were checked with 95 per cent probability and two-tailed distribution, having $\mathrm{p}$ values above the 0,05 meaning. That imposes above implications being not significant. These findings could be correct by enlarging the set of data.

However, all presumptions made are excused from causal relations. Moreover, these results according their trends of dynamics are the closest to scenario no. 1 (Basic). 
To sum up all the scenarios the Table 9 is introduced, showing the differences between each scenario comparing to basic one.

Table 9. Summary of differences in scenarios results*

\begin{tabular}{|r|c|c|c|c|}
\hline Correlations to & Scenario 1 - r & Scenario 2 - r & Scenario 3 - r & Scenario 4 - r \\
\hline unemployment & & 0,01 & 1,37 & $-0,23$ \\
\hline inflation & & 0,15 & $-0,77$ & 0,18 \\
\hline av.wage & & 0,32 & $-1,15$ & 0,48 \\
\hline budget revenue & & $-0,58$ & $-0,44$ & $-0,47$ \\
\hline
\end{tabular}

*compiled by author

The biggest differences are observed in the third scenario comparing to the first, where meanings of indicators are changing in times. This scenario was exclusive emphasizing the mostly negative trend of its differences (near all indicators were decreasing). The second and the fourth scenarios keep changes in similar amounts of trends. However, different indicators differ in meanings and there is no unified presumption for all.

In order to group the changes in scenarios by changes in GDP growth (to which the scenarios were adopted) and to measure the sensitivity of the indicator, one can observe the largest changes in pessimistic environment comparing to realistic and optimistic ones.

To sum up all the analysis done, one cannot rely on presumption made due to the lack of data in the analysis. However, the predictions for further researches could be stated: the relationships between crowdfunding and indirect impact economic indicators (e.g. unemployment, inflation, etc.) often are stronger then direct impact indicators (e.g. budget revenue). Moreover, positive scenarios are less sensitive to changes of economic indicators, than negative ones.

According to the chosen state's example, if the conclusions of the analysis were significant, there is no difference between the form of the reward of crowdfunding, if the case studies in volume are similar.

\section{Conclusions}

After the theoretical analysis and what-if approach to crowdfunding the following conclusions were made:

1) Different kind of features are emphasized while crowdfunding is described. Most common are the way of organizing it and the tool used.

2) Classification of crowdfunding is broadened by direct and indirect finance approach as well as reward is being classified in production and services and financial reward (see Fig 1). 
3) According to the basic scenario, the unemployment and crowdfunding market has middle strong negative $(\mathrm{r}=-0,53)$ linear correlation. When there are growing crowdfunding funds, the unemployment is decreasing. Inflation, wage and budget revenue indicators could be described as of middle strong positive correlation to crowdfunding ( $\mathrm{r}$ meanings around 0,5 ). When crowdfunding projects increase, the inflation, average wage in the country and budget revenue indicators also increase.

4) The relationships between crowdfunding and indirect impact economic indicators (e.g. unemployment, inflation, etc.) often seemed to be stronger then direct impact indicators (e.g. budget revenue). Moreover, positive scenarios were less sensitive to changes of economic indicators, than negative ones.

5) Analyzing the differences between different forms of the rewards, according to Lithuania's tax system, there were too lack of difference for the separate analysis, unless would be a remarkable difference in volumes.

The proposals for the future research:

1) To fulfill the research by classification of countries, where crowdfunding is developed and under development.

2) To enlarge the period of data, for the significance of the analysis.

\section{References}

Agrawal, A.K., Catalini, C., Goldfarb, A. (2011) "The Geography of Crowdfunding", NBER Working Paper No. 16820, [Online], Available: http://www.nber.org/papers/w16820 [24 June 2017].

Agrawal, A.K., Catalini, C., Goldfarb, A. (2013) "Some Simple Economics of Crowdfunding“, NBER Working Paper No. 19133, [Online], Available: http://www.nber.org/papers/w19133 [24 June 2017].

Belleflamme, P., Lambert, T., Schwienbacher, A. (2010) "Crowdfunding: An Industrial Organization Perspective“, [Online], Available: https://economix.fr/pdf/workshops/2010_dbm/Belleflamme_al.pdf [26 June 2017].

Belleflamme, P., Lambert, T., Schwienbacher, A. (2013) "Individual crowdfunding practices“, An International Journal of Entrepreneurial Finance 15(4), [Online], Available: http://www.tandfonline.com/doi/abs/10.1080/13691066.2013.785151 [24 June 2017].

Belleflamme, P., Lambert, T., Schwienbacher, A. (2014) "Crowdfunding: Tapping the right crowd“, Journal of Business Venturing, vol. 29, no. 5, pp. 585-609.

Buysere, K.D., Gajda, O., Kleverlaan, R., Marom, D. (2012) “A Framework for European Crowdfunding, 1st ed.", [Online], Available from Internet: http://www.infoeuropa.ciejd.pt/files/database/000051001-000052000/000051102.pdf [30 June 2017].

ECB (2016). "Survey on the access to finance of enterprises", [Online], Available: https://www.ecb.europa.eu/stats/ecb_surveys/safe/html/index.en.html [cited 30 June 2017]. 
Gerber, E.M. and Hui, J. (2013) "Crowdfunding: Motivations and deterrents for participation", ACM Transactions on Computer-Human Interaction (TOCHI) 20(6), [Online],

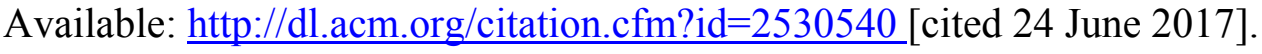

Gueyie, J. P., Manos, R., Yaron, J. (2013). Microfinancing in Developing Countries: Issues, Policies and Performance evaluation, New York: Palgrave Macmillan.

Hermer, J. (2011) "A Snapshot on Crowdfunding“, Working Papers Firms and Region No. $R 2 / 2011$

[Online], Available:

http://www.isi-lehre.de/isiwGlobal/wGlobal/scripts/accessDocument.php? wAuthIdHtaccess $=800364842$ \&document $=/$ is iwAssets/docs/p/de/arbpap unternehmen region/ap_r2 2011.pdf\&display=1\& forceDownloa $\underline{\mathrm{d}=0}$ [30 June 2017].

Mollick, E. (2014) "The dynamics of crowdfunding: An exploratory study", Journal of Business Venturing, vol. 29, no. 1, pp. 1-16.

Rizzi, S. (2008) "What-If Analysis", [Online], Available: $\underline{\text { http://www- }}$ db.deis.unibo.it/ srizzi/PDF/eds-WIA.pdf [14 July 2017].

Rubinton, B.J. (2011) "Crowdfunding: Disintermediated Investment Banking", [Online],. Available: https://papers.ssrn.com/sol3/papers.cfm?abstract id=1807204 [30 June 2017].

The Law of crowdfunding of Repuclic of Lithuania (2016). Available: http://www.lrs.lt/sip/portal.show?p_r=119\&p_k=1\&p_t=166710 [30 June 2017]. 